\title{
EXTENDED SPECTRUM OF B- LACTAMASE STATUS IN ESCHERICHIA COLI ISOLATED FROM URINARY TRACT INFECTIONS IN DUHOK CITY - IRAQ
}

\author{
Nebal SAmi Michael ${ }^{*}$ and Abdulrahman T SAAdi ${ }^{* *}$ \\ *Dept. of Microbiology, College of Pharmacy, University of Duhok, Kurdistan Region-Iraq \\ ***pt. of Microbiology, College of Medicine, University of Duhok, Kurdistan Region-Iraq
}

(Received: May 6, 2018, Accepted for publication: November 26, 2018)

\begin{abstract}
Objectives: To study the pattern of ESßL $E$. coli in cross sectional study from urine of patients in Azadi and Heve Paediatric Teaching Hospitals in Duhok city.

Methods: This study was conducted between June 2016 and December 2016. A study of 325 of E.coli isolates from urine samples in Azadi Teaching Hospital and 420 isolates from Heve Teaching Hospital. Confirmation of ES $\beta$ L production was performed using double-disk synergy test and the BD Phoenix automated system..

Results: There were $175(53.8 \%)$ confirmed strains of ESßLs E. coli among adults from Azadi Hospital and $163(38.8 \%)$ strains among paediatrics from Hevi Hospital which were tested by double-disk synergy test and BD Phoenix. There was no statistical significance for ESßL strains regarding the gender of the patients. Majority of ES $\beta L$ E. coli were among 7-9 years and 25-65 years. The rate of antibiotic resistance was $>\mathbf{9 0 \%}$ for Ceftazidime, Ceftriaxone, Cefixime, Cefepime, Augmentin and Aztreonam for both adults and paediatric age groups. The rate of sensitivity for Imipenem, Amikacin and Nitrofurantoin was $4.5 \%$, $\mathbf{8 \%}$ and $16 \%$ respectively for adults and $17 \% 15.5 \%$ and $24.5 \%$ for paediatrics respectively.
\end{abstract}

Conclusion: Increasing E.coli from both hospitals. Exposures to antibiotics, previous hospital admission, recurrent urinary tract infection and diabetes were risk factors for ESßLs.

\section{INTRODUCTION}

$\mathbf{U}$ rinary Tract Infection (UTI) is one of the most common bacterial infections and it is commonly treated in primary health care ${ }^{1}$. The most common cause of UTI is extraintestinal pathogenic E. coli affecting more than $70 \%$ of community-acquired UTIs ${ }^{2}$.

The widespread use of third-generation cephalosporins and aztreonam has led the emergence of the extended spectrum $\beta$ lactamases (ES $\beta$ Ls) results from mutations in $\beta$ lactamases. ES $\beta$ Ls are plasmid-mediated enzymes that are inhibited in vitro by clavulanate $^{3}$. As they are clavulanate susceptible enzymes conferring broad resistance to penicillins, aztreonam and cephalosporins and are detected most commonly in Klebsiella pneumoniae and E.coli ${ }^{4}$. It has been shown that recurrent UTI is one of the risk factors for ES $\beta \mathrm{L}$ producing $E$. coli infections in hospitalized ${ }^{5}$ and non-hospitalized patients ${ }^{6,7}$. The great increase in ES $\beta$ L-producing E.coli, found to be the reason for higher morbidity, prolonged hospitalization and increased health care costs. This is a major public health problem in both hospitals and communities ${ }^{8}$.

There has been an interest in the epidemiological factors associated with infections caused by ES $\beta$ L E.coli: age > 65 years, male sex, previous UTI, use of antibiotics and hospitalization as common risk factors ${ }^{9,10}$.

There are several ES $\beta$ s genotypes. The most common of these are the SHV, TEM, and CTX$M^{11}$. They have emerged to be a major cause of hospital acquired infections, especially in intensive care unit ${ }^{12}$. These ES $\beta$ L-producing strains represent a significant therapeutic challenge as they are resistant to all currently available $\beta$-lactam antibiotics but cephamycins (cefoxitin and cefotetan) and carbapenems (imipenem and ertapenem) is of a transmissible nature, i. e. plasmid-coded in some strains of nosocomial Enterobacteriaceae. ${ }^{13}$. 
The importance of the present study in our locality is to find out the associated risk factors for ESBLs - E.coli compared to non- ESBLs E.coli and To determine if the positive ES $\beta$ Ls E.coli cultures are acquired from the hospital or from the community.

The aim of the current study is screening of the ES $\beta$ L- E. coli in urine samples of patients with UTIs in Duhok city.

\section{METHODS}

\section{Sample collection:}

A total of $325 E$. coli were collected from outpatients with UTIs whom attended the General Azadi Teaching Hospital and a total of $420 E$. coli from Heve paediatric Teaching Hospital in Duhok city.

Socio-demographic and clinical information were obtained from medical records and included: age, gender, recent antibiotics intake within the last 3 months, diseases (Diabetes and recurrent urinary tract infection), previous admission to hospital within the last 3 months, intermittent catheterization and Long duration of prophylaxis treatment.

\section{Bacterial cultures:}

All urine samples were inoculated on blood agar, MacConkey agar plates and Kligler agar (Oxoid, UK). These plates were incubated overnight at $37{ }^{\circ} \mathrm{C}$ aerobically. All isolates were identified based on their colony, morphology, culture characteristics, and biochemical reactions according to the standard microbiological procedures $^{14}$. Only those samples were processed for ES $\beta$ Ls production that showed significant growth and were identified as $E$. coli on the basis of culture and biochemical characteristics.

Identification for all the bacterial isolates were further determined using the BD Phoenix ${ }^{\mathrm{TM}}$ automated machine in General Azadi Teaching Hospital.

\section{Processing of samples:}

The bacterial isolates were phenotypically investigated in Microbiology Laboratory in General Azadi Teaching Hospital.

\section{Screening for ES $\beta$ Ls}

The ES $\beta$ Ls screening was performed according to National Committee for Clinical Laboratory Standards (NCCLS): ES $\beta$ L E. coli producers were identified first by disc diffusion technique using Ceftazidime $(\leq 22 \mathrm{~mm})$, Cefotaxime $(\leq 27 \mathrm{~mm})$, Ceftriaxone $(\leq 25 \mathrm{~mm})$ and Aztreonam $(\leq 27 \mathrm{~mm})$. If the isolates are resistant to any of these drugs, they are considered as suspect of ES $\beta$ L producers ${ }^{15}$. Both Double Disc Synergy Test (DDST) and Phoenix ${ }^{\mathrm{TM}}$ automated machine were performed for confirmation.

\section{Confirmation of ES $\beta$ Ls}

All isolates that have been found to be resistant to cefotaxime, ceftazidime, ceftriaxone and Aztreonam were subjected to confirmatory tests by the double disc diffusion methods, following the CLSI guidelines ${ }^{16}$. Mueller Hinton agar plates were classified according to 0.5 McFarland tube). Three 3rd generation cephalosporin with one monobactam (aztreonam $30 \mu \mathrm{g})$ discs were placed at $20 \mathrm{~mm}$ distance from augmentin disc.

\section{Susceptibility test}

All the isolates were screened for antibacterial sensitivity using "Kirby-Bauer method" according to CLSI standards ${ }^{17}$. This test was performed on Muellar Hinton agar medium (Oxoid Ltd, England). 17 AST discs (Bioanalyse) were used: Amoxicillin/Clavulanic

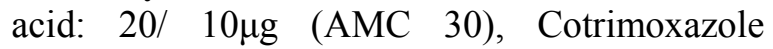
$1.25 / 23.75 \mu \mathrm{g}$ (SXT), Ciprofloxacin $10 \mu \mathrm{g}$ (CIP), Nitrofurantoin $100 \mu \mathrm{g}(\mathrm{F})$, Nalidixic acid $30 \mu \mathrm{g}$ $(\mathrm{Na})$, Ceftriaxone $10 \mu \mathrm{g}$ (CRO), Gentamicin $10 \mu \mathrm{g} \quad(\mathrm{CN}), \quad$ Ceftazidime $30 \mu \mathrm{g} \quad$ (CAZ),

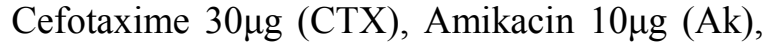

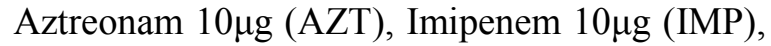
Cefixime $5 \mu \mathrm{g}$ (CFM), Piperacillin $30 \mu \mathrm{g}$ (PRL), Cephalothin $30 \mu \mathrm{g}$ (Kf), Meropenim $10 \mu \mathrm{g}$

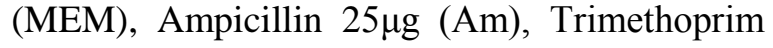
$10 \mu \mathrm{g}$ (TMP) and Metronidazole 30 $\mu \mathrm{g}$ (MET).

\section{Statistical analysis:}

A descriptive analysis was applied to the study sample and expressed as means \pm standard deviation, frequencies and percentages. Data were analyzed using the SPSS v16.0 statistical package (SPSS Inc, Chicago, IL, USA).

\section{RESULTS}

During the study period between June 2016 and December 2016, out of 325 E. coli isolates 200 isolates among adults from General Azadi Hospital and 200 isolates out of 420 among children from Heve Hospital were identified as ES $\beta$ Ls by Phoenix and included in the study. 
Regarding to gender of patients, $47 \%$ of the ES $\beta \mathrm{L}$ isolates were isolated from males and $53 \%$ of the isolates were isolated from females in Heve Teaching Hospital, while in General Azadi

Table(1):-Frequencies and percentages

\begin{tabular}{|c|c|c|}
\hline Age group (years) & $\begin{array}{c}\text { Number (No.) } \\
\text { positive ES } \beta \text { Ls } \\
(200)\end{array}$ & $\begin{array}{c}\text { Percentages }(\%) \text { of positive } \\
\text { ES } \beta \text { Ls } \\
(200)\end{array}$ \\
\hline \multicolumn{3}{|l|}{ (Paediatrics) } \\
\hline $1-3$ & 108 & 54 \\
\hline $4-6$ & 33 & 16.5 \\
\hline $7-9$ & 44 & 22 \\
\hline $10-14$ & 15 & 7.5 \\
\hline \multicolumn{3}{|l|}{ (Adults) } \\
\hline $15-24$ & 61 & 30.5 \\
\hline $25-65$ & 130 & 65.5 \\
\hline 66 and more & 9 & 4.5 \\
\hline
\end{tabular}

The pattern of ES $\beta \mathrm{L}, \mathrm{AmpC}$ and
Carbapenemase among patients from both hospitals are shown in Table 2.
The pattern of ES $\beta \mathrm{L}, \mathrm{AmpC}$ and
Hospital $52.5 \%$ were males and $47.5 \%$ were females. During this study, the distribution of ES $\beta \mathrm{L}$ in both paediatric and adult is shown in Table 1.
There were high percentage of ES $\beta$ Ls producing $E$. coli among adult patients (53.8\%) and paediatric patients $(38.8 \%)$, when compared with AmpC and Carbapenemase types.

Table(2):- Pattern of ES $\beta \mathrm{L}, \mathrm{AmpC}$ and Carbapenemase isolates of $E$. coli among patients

\begin{tabular}{ccc}
\hline Types of ESBL & $\begin{array}{c}\text { Frequency (Mean) for adults } \\
\text { No.=200 }\end{array}$ & $\begin{array}{c}\text { Frequency (Mean) for paediatrics } \\
\text { No. }=200\end{array}$ \\
\hline ESBL & $175(53.8 \%)$ & $163(38.8 \%)$ \\
\hline AmpC & $21(6.46 \%)$ & $33(7.86 \%)$ \\
\hline Carbapenemase & $4(1.23 \%)$ & $4(0.95 \%)$ \\
\hline
\end{tabular}

Regarding to the risk factors, it was obvious from (table 3$)$, there were $(73.5 \%)$ among adult and $(67.0 \%)$ in paediatric patients related to previous hospital admission, while in diabetic patients the risk factor for paediatric patients $(63.5 \%)$ and adult patients (42\%) at the same time, the adult patients with recurrent UTIs had $18 \%$ ES $\beta$ Ls producing $E$. coli and paediatric patients with recurrent UTIs had 54\%. Treatment with amoxiclave was $(62.5 \%)$ and treatment with Ciprofloxacin was $(27.0 \%)$ of ES $\beta$ Ls producing E. coli during the last 3 months.

Table (3):- Developing an infection with ES $\beta$ L by different effects

\begin{tabular}{ccc}
\hline Risk factors & $\begin{array}{c}\text { Paediatric } \\
\text { patients ESBLs } \\
\text { positive (200) }\end{array}$ & $\begin{array}{c}\text { Adult patients } \\
\text { ESBLs positive } \\
\mathbf{( 2 0 0 )}\end{array}$ \\
\hline Diabetes & $127(63.5 \%)$ & $84(42.0 \%)$ \\
\hline Recurrent UTIs & $108(54.0 \%)$ & $36(18.0 \%)$ \\
\hline Previous hospital admission & $134(67.0 \%)$ & $147(73.5 \%)$ \\
\hline $\begin{array}{c}\text { Taking Amoxiclave within the last 3 } \\
\text { months }\end{array}$ & $/$ & $125(62.5 \%)$ \\
\hline $\begin{array}{c}\text { Taking Ciprofloxacin within the last 3 } \\
\text { months }\end{array}$ & $54 / 200(27.0 \%)$ \\
\hline
\end{tabular}

All isolates that had been resistant to third generation cephalosporin were found to show positive synergy by the double disc diffusion test indicating the presence of ES $\beta$ s
All the ES $\beta$ L producing $E$. coli among adults were resistant to ampicillin and Amoxiclave but it was $71.5 \%$ and $91 \%$ respectively among paediatric patients. It was $98.5 \%$ resistant for both Cefixim and Ceftazidim and $98 \%$ for both 
Ceftriaxone and Aztreonam among adults and they were $79 \%, 94.5 \%, 905$ and $95 \%$ respectively among children. The patterns of the other antimicrobials tests for both adults and paediatrics are shown in Table 4.

Table(4):- Antibiotic Resistance patterns of ES $\beta$ Ls

\begin{tabular}{|c|c|c|}
\hline & $\begin{array}{c}\text { Resistance among } \\
\text { paediatrics (200) }\end{array}$ & $\begin{array}{c}\text { Resistance among } \\
\text { adults (200) }\end{array}$ \\
\hline Amikacin $(\mathrm{AK}, 10 \mu \mathrm{g})$ & $31(15.5 \%)$ & $16(8.0 \%)$ \\
\hline Gentamicin $(\mathrm{CN}, 10 \mu \mathrm{g})$ & $97(48.5 \%)$ & $117(58.5 \%)$ \\
\hline Emipenem (IMP, $10 \mu \mathrm{g})$ & $34(17.0 \%)$ & $9(4.5 \%)$ \\
\hline Cifixime $(\mathrm{CFM}, 5 \mu \mathrm{g})$ & $158(79.0 \%)$ & $197(98.5 \%)$ \\
\hline Ceftazidime (CAZ, $30 \mu \mathrm{g})$ & $189(94.5 \%)$ & $197(98.5 \%)$ \\
\hline Ceftriaxone $(\mathrm{CRO}, 10 \mu \mathrm{g})$ & $180(90.0 \%)$ & $198(98.0 \%)$ \\
\hline Cefepime (CFM, $30 \mu \mathrm{g})$ & $163 / 200(81.5 \%)$ & $190 / 200(95.0 \%)$ \\
\hline Aztreonam (AZT, $10 \mu \mathrm{g})$ & $190 / 200(95.0 \%)$ & $196 / 200(98.0 \%)$ \\
\hline Ampicillin $(\mathrm{AM}, 25 \mu \mathrm{g})$ & $143 / 200(71.5 \%)$ & $200 / 200(100 \%)$ \\
\hline Co-Amoxiclave: Amoxicillin-Clavulanate (AMC 20/10 $\mu \mathrm{g})$ & $190 / 200(95.0 \%)$ & $200 / 200(100 \%)$ \\
\hline Pipracillin (PIP, $30 \mu \mathrm{g})$ & $67 / 200(33.5 \%)$ & $117 / 200(58.5 \%)$ \\
\hline Trimethoprim $(\mathrm{TMP}, 10 \mu \mathrm{g})$ & $140 / 200(70.0 \%)$ & $149 / 200(74.5 \%)$ \\
\hline Nitrofurantoin $(F, 100 \mu g)$ & $49 / 200(24.5 \%)$ & $32 / 200(16.0 \%)$ \\
\hline Ciprofloxacin (CIP, $10 \mu \mathrm{g})$ & $89 / 200(44.5 \%)$ & $165 / 200(82.5 \%)$ \\
\hline Norfloxacin & $70 / 200(35.0 \%)$ & $172 / 200(86.0 \%)$ \\
\hline Metronidazole (MET, $30 \mu \mathrm{g})$ & $102 / 200(51.0 \%)$ & $93 / 200(46.5 \%)$ \\
\hline Nalidixic Acid $(\mathrm{N}, 30 \mu \mathrm{g})$ & $58 / 200(29.0 \%)$ & $81 / 200(40.5 \%)$ \\
\hline
\end{tabular}

\section{DISCUSSION}

This study revealed that the overall ratio of male to female UTI patients in $<14$ years of age was 0.89 however the ratio was 1.11 in adults of General Azadi Teaching Hospital. These ratios were not statistically significant. This is in agreement with a study done by ${ }^{18}$. While, a study done by ${ }^{19}$, among the ES $\beta$ Ls producing isolates of $E$ coli found 100/484 (20.7\%)

were infecting males while 384/484 (79.3\%) were infecting females. Moreover a study done by $^{20}$ illustrates a relation of ES $\beta$ Ls for both sexes. Nevertheless, found male sex is an independent predictive risk factor for ES $\beta$ Ls.

The current study found that the frequencies of ES $\beta \mathrm{L}$ was prevalent among all age groups but the highest percentage was for those less than 3 years of age and this can be attributed to low immunity among the neonates. A study done by $^{21}$, found that age > 65 years was independently predictive of ES $\beta \mathrm{L}$ positivity.

A study done by ${ }^{22}$ has shown the risk factors for UTIs to be previous infections and exposure to antibiotics also posing a major risk for UTIs with resistant bacteria. The same researcher has found recent hospitalization, administration of antibiotics effects on ES $\beta$ Ls.

More generally, different studies have shown conflicting relations for sexes and infection due to ES $\beta$ L-producing Enterobacteriaceae ${ }^{23-26}$.

Different ES $\beta$ Ls exhibit different levels of resistance to third generation cephalosporins ${ }^{27}$. A wide range of activity of antimicrobial resistance pattern to the antimicrobial agents was observed in ES $\beta \mathrm{L}$ E. coli. A high degree of resistance (> $90 \%$ ) was seen in $3^{\text {rd }}$ and $4^{\text {th }}$ generation Cephalosporin (Ceftriaxone, Ceftazidime, Cefepime, Cefixime) and Aztreonam. Also, Amoxicillin-Clavulanate. Intermediate level of resistance $(40 \%-70 \%)$ was observed in Gentamicin, Pipracillin,Trimethoprim, Metronidazole and Nalidixic Acid. The least resistance was observed among Emipenem, Amikacin and Nitrofurantoin ${ }^{27}$.

In conclusion, the results of the present study revealed that there is high distribution of ES $\beta$ Ls among E. coli isolates from both hospitals. Exposures to antibiotics, previous hospital admission, recurrent urinary tract infection and diabetes were risk factors for ES $\beta$ Ls. This study 
has important implications for public health, especially in relation to UTIs in women.

\section{REFERENCES}

- Foxman B. The epidemiology of urinary tract infection (2010) Dec. Nat Rev Urol. Nature Publishing Group; 7 (12):653-60.

- Kahlmeter G, Poulsen HO. (2012); Jan. Antimicrobial susceptibility of $E$ coli from communityacquired urinary tract infections in Europe: the ECO-SENS study revisited. Int $\mathrm{J}$ Antimicrob Agents. Elsevier B.V.; 39 (1):4551.

- Paterson DL, and Bonomo RA. (2005). Extendedspectrum $\beta$-lactamases: a clinical update, Clin. Microbiol. Rev; 18: 657-686

-. Conceição T, Brízio A, Duarte A, Barros R (2005). First isolation of bla (VIM-2) in Klebsiella oxytoca clinical isolates from Portugal. Antimicrob Agents Chemother; 49 (1):476.

-. Briongos-Figuero LS, Gómez-Traveso T, BachillerLuque P, González MD-G, Gómez-Nieto A, Palacios-Martín T, et al. (2012). Epidemiology, risk factors and comorbidity for urinary tract infections caused by extended-spectrum beta-lactamase (ESBL)producing Enterobacteria. Int J Clin Pract. 66: 891-896.- Rodríguez-Bano J, Navarro MD, Romero L, Martínez-Martínez L, Muniain MA, Perea EJ, et al. (2004). Epidemiology and clinical features of infections caused by ESBL-producing $E$ coli in nonhospitalized patients. J Clin Microbiol 42: 1089-1094.

- Rodríguez-Bano J, Alcala JC, Cisneros JM, Grill F, Oliver A, Horcajada JP, et al. (2008). Community infections caused by extendedspectrum $\beta$-Lactamase-producing Escherichia coli. Arch Intern Med 168: 1897-1902.

- Schito GC, Naber KG, Botto H, Palou J, Mazzei T, Gualco L, et al. (2013). The ARESC study: an international survey on the antimicrobial resistance of pathogens involved in uncomplicated urinary tract infections. Int JAntimicrob Agents. 34: 407-13.

- Doi Y, Park YS, Rivera JI, Adams-Haduch JM, Hingwe A, Sordillo EM, et al. (2009). Community associated extended-spectrum $\beta$ - lactamase-producing Escherichia coli infection in the United States. Clin Infect Dis. 56(5):641-8.

- Søraaas A, Sundsfjord AS, Sandven I, Brunborg C, Jenum PP a, Søraas A. (2013). Risk factors for Community - Acquired Urinary Tract Infections caused by ESBL-producing Enterobacteriaceae. A Case Control Study in a Low Prevalence Country. PLoS One. 8 (7):17.

- Rupp, ME and Fey, PD (2003). Extended spectrum $\beta$-lactamase (ESBL) producing Enterobacteriaceae: considerations for diagnosis, prevention, and drug treatment. Drugs; 63:353-65.

- Falagas, ME and Karageorgopoulos D E. (2009). Extended spectrum $\beta$ Lactamase producing organisms.J. Hosp. Infection 4: 345-354.

- Knothe H, Shah P, Krcmery V, Antal M, Mitsuhashi S (1983). Transferable resistance to cefotaxime, cefoxitin,

cefamandole and cefuroxime in clinical isolates of Klebsiella pneumoniae and Serratia marcescens. Infection. 11: $315-7$.

- Mahon CR, Lehman DC, Manuselis G2014. Textbook of Diagnostic Microbiology 5th Edition.

-. CLSI. (2006). Clinical and Laboratory Standards Institute (CLSI): Performance Standard for Antimicrobial Susceptibility Testing. 16th Informational supplement. CLSI document,. M100-S16.

- Jacoby G A and Medeiros A A. (1991). More extended-spectrum beta lactamases. Antimicrobial agents and chemotherapy. 35 (9): 1697-1704.

-. Leigue L., Montiani F. and B.A. Moore B A. (2016). Antimicrobial susceptibility and minimal inhibitory concentration of Pseudomonas aeruginosa isolated from septic ocular surface disease in different animal species. Open Veterinary Journal. Vol. 6(3): 215-222

- Abdur Rahim M, Samad T, Mitra P, Zaman S, Habib S H, Afroze S R, Mohosin W M, Haque UI and Nazim Uddin K. (2017). 
Frequency, Risk Factors and Antibiotic Sensitivity Pattern of Extended-Spectrum Beta-Lactamase Producing $E$. coli and $K$. pneumoniae Causing Urinary Tract Infection: Experience from a Tertiary Care Hospital of Bangladesh. Birdem Medical Journal.

- Ahmed I, Sajed M, Sultan A, MurtazaI, Yousaf S, Maqsood B, Vanhara P, Anees M (2015). The eratic antibiotic susceptibility patterns of bacteria. Pathogens causing Urinary Tract Infections. EXCLI Journal. 14:916-9.

-. Pitout JD, Hanson ND, Church DL, Laupland KB (2004). Population-based laboratory surveillance for Escherichia coli-producing extended-spectrum b-lactamases: importance of community isolates with bla CTXM genes. Clin Infect Dis. 38:1736-41.

-. Ronen Ben-Ami, Jesu's Rodrı'guez-Baño, Hande Arslan, Johann D. D. Pitout, Claudine Quentin, Esther S. Calbo, O“zlem K. Azap, Corinne Arpin, Alvaro Pascual, David M. Livermore, Javier Garau, and Yehuda Carmeli(2009). A Multinational Survey of Risk Factors for Infection with ESBLProducing Enterobacteriaceae in Nonhospitalized Patients. CID. $49 \quad$ (1 September).

- Foxman B. (2014). Mar Urinary tract infection syndromes: occurrence, recurrence, bacteriology, risk factors, and disease burden. Infect Dis Clin North Am. Elsevier Inc; ;28 (1):1-13.

-. Novais A, Cantøn R, Valverde An, et al. (2006).. Dissemination and persistenceof blaCTX-M-9 are linked to class 1 integrons containing CR1 asso-ciated with defective transposon derivatives from Tn402 located in early antibiotic resistance plasmids of IncHI2, IncP1- alpha, and IncFIgroups. Antimicrob Agents Chemother 50:2741-50.23.

- Lavollay M, Mamlouk K, Frank T, et al. (2006). Clonal dissemination of aCTX-M-15 blactamase-producing Escherichia coli strain in theParisarea,Tunis, and Bangui. Antimicrob Agents Chemother; 50:2433-8.24.

- Coque TM, Novais A, Carattoli A, et al. (2008). Dissemination of clonally related Escherichia coli strains expressing extended-spectrum blactamase CTX-M-15. Emerg Infect Dis; 14:1

- Schwaber MJ, Navon-Venezia S, Schwartz D, Carmeli Y. (2005). High levels of antimicrobial co-resistance among extended spectrum b lactamase producing Enterobacteriaceae. Antimicrob Agents Chemother; 49: 2137 - 9.

-. Gupta, V. (2007). An update on newer $\beta$ lactamases. Indian J Med Res 126: 417-427.

\footnotetext{
يوخته

ئامانجهكان

زانينى و ناسينهوهى جوّرهكانى E.coli ESBL يشكنينى دزه مينه

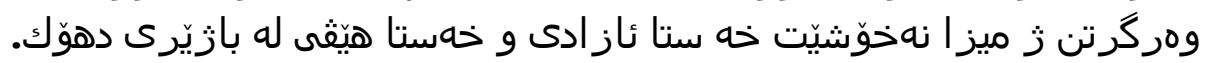

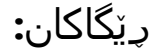

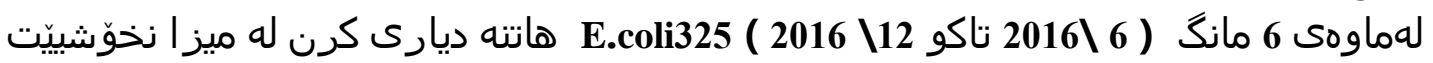

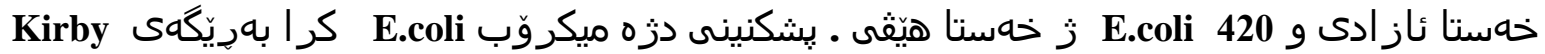

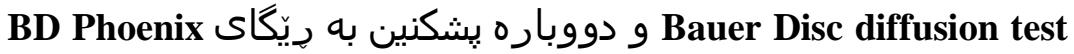
ئهزجام:

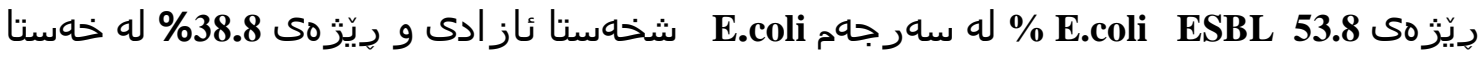

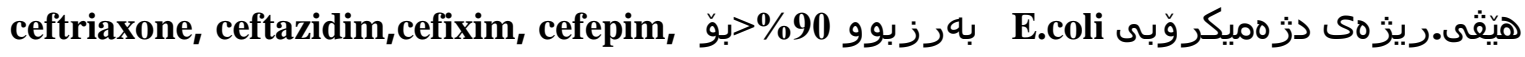
augmentin and Aztreonam Nitrofurantion
} 
ديزئ ESBL درئهزجام:

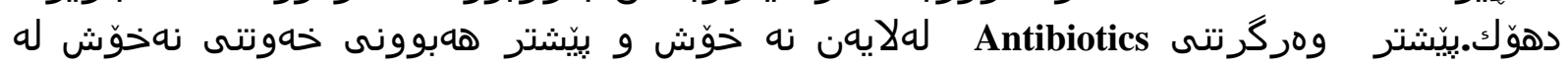

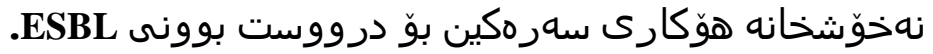
الخلاصو الهوخه دراسه ESBL عند بكتيريا Eoli المعزوله من التهابات المجاري البوليه لمدينه دهوك- العراق. الاهداف: معرفه انتشار بكتريا E.coli والمقاومه لعدد من المضادات الحيويه والمعروفه ب (ESBL) في ادرار مرضى مستشفى از ادي التعليمي ومستشفى هيفي التعليمي في مدينه دهوك- عراق اق مركهات

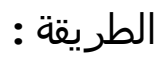
تمت الدر اسه على 325 عزله E.coli من مرضى مستشفى از ادي و420 عزله من مستشفى هيفي للفتره من حزيران 2016 ولغايه كانون الاول 2016. في البدايه تح عزل بكتيريا ال E.coli المقاومه مرله

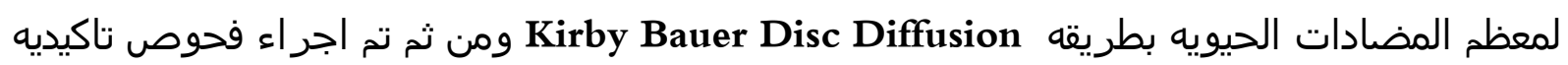
باجراء Double Disc Diffusion ومن ثم بجهاز ال Phoenix للتعرف على نوعها ومدى استجابتها للمضادات الحيويه. النتائج:

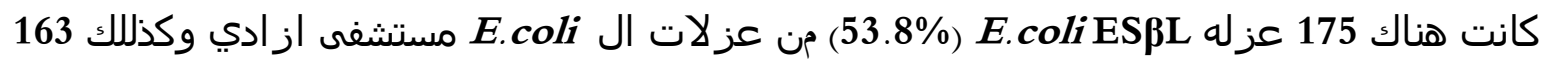

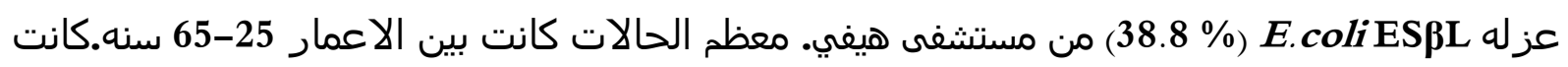

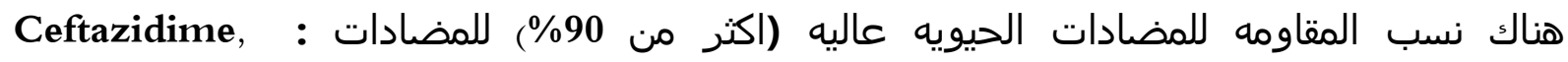
Ceftriaxone, Cefixim, Cefepime, Augmentin, and Aztreonam.

Aitrofurantoin (16\%) وكذلك Amikacin (8\%) و (Imipenem 4.5\%) الاستنتاجات: اشارت الدراسه ان هناك نسبه عاليه لESß E.coli المقاومه لمعظم المضادات الحيويه من ادرار

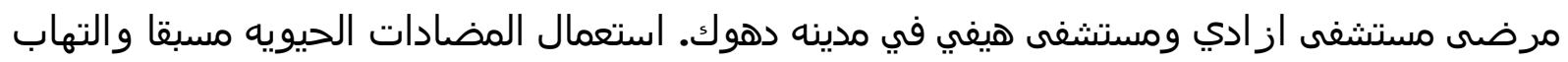

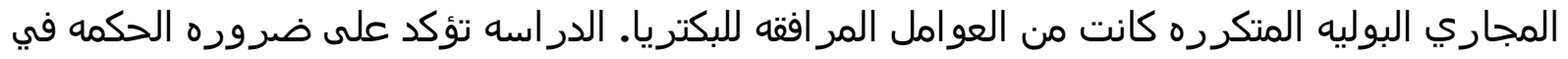

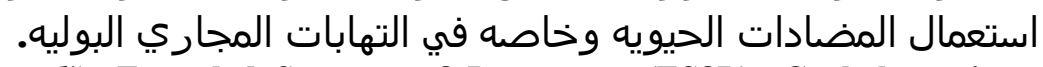
KEYWORDS: Escherichia coli (E. coli); Extended Spectrum $\beta$-Lactamase (ES $\beta$ L); Cephalosporines; Carbapenems; BD Phoenix and ESBLs genotypes SHV, TEM, and CTX-M. 